\title{
Drying Contraction Assessment of Ceramic Products Produced by Extrusion or Pressing Formulated with Sheep Wool Waste
}

\author{
Cristiano Corrêa Ferreira ${ }^{*}$, Francine Machado Nunes ${ }^{a}$, Luan Teixeira de Oliveira ${ }^{a}$, \\ Gabriela Rossatto Cáceres ${ }^{a}$, Gabryella Cerri Mendonça ${ }^{a}$, Rui Rosa de Morais $\mathrm{Jr}^{b}$ \\ ${ }^{a}$ Federal University of Pampa - UNIPAMPA, Bagé, RS, Brazil \\ ${ }^{b}$ Federal University of Rio Grande - FURG, Rio Grande, RS, Brazil
}

Received: December 08, 2016; Revised: April 17, 2017; Accepted: May 02, 2017

\begin{abstract}
The main aim of this paper was to evaluate ceramic products containing a percentage of ash from sheep wool waste through drying linear shrinkage from a small brickyard in Bagé - RS. The ash percentages used in the formulation were $0,5,10,20$ and 30\%. Raw materials were analyzed by Energy Dispersive X - ray Fluorescence (XRF/EDX). The methods used to shape the ceramic products were vacuum extrusion and pressing. After shaping, the ceramic products were dried in laboratory conditions with an average temperature of $21^{\circ} \mathrm{C}$ for 3 weeks and later in an oven at $110^{\circ} \mathrm{C}$ for $48 \mathrm{~h}$. The drying linear shrinkage test was performed according to the specifications of standard C-021/95, and its average results for all formulations were $8.2 \%$ and $0.7 \%$, for the extruded and pressed products, respectively. The results of drying linear shrinkage were higher for the extruded products than for the pressed ones, showing that the addition of the ash from the sheep wool waste in the clay decreased the drying linear shrinkage in the extruded ceramic products.
\end{abstract}

Keywords: Red ceramic, sheep wool ash, vacuum extrusion, pressing, drying linear shrinkage

\section{Introduction}

In ceramic industries, products obtained from clay can be shaped using pressing or extrusion methods. The pressing method uses low humidity index (below 5\%) in order to shape ceramic products ${ }^{1}$. On the other hand, vacuum extrusion uses the humidity index for conformation between 18 and $25 \%$ in mass $^{2}$.

Industrial waste may be incorporated into clay to produce ceramic materials in order to reduce plasticity and decrease the degree of compaction of the loamy mass. As a result, this possibility favors the drying stage of the products since the added residue helps the water path from the inside to the surface of the ceramic materials ${ }^{3}$.

There are a variety of materials that may be incremented into clay to produce ceramic products. Plenty of researchers have been using residue in the formulation of construction materials, such as bricks ${ }^{4,5}$, tiles, and ceramic blocks ${ }^{6,7}$. However, there are no prior studies with sheep wool ash in the formulation of ceramic products to prove its application.

The Campanha Meridional micro-region of Rio Grande do Sul state, which includes cities such as Dom Pedrito and Bagé, has the largest flock of sheep in Brazil. The animals are raised mainly for wool production, and this industry is a well-recognized economic activity in the textile industry of the region ${ }^{8,9}$.

In the textile industry, the wool processing stage generates high amounts of waste, which may contain dirt, sand, insects, fiber, organic matter and manure ${ }^{10}$.

* e-mail: cristiano.unipampa@gmail.com
Thereby, the incorporation of shape wool in the production of ceramic blocks is an alternative form of recycling ${ }^{11}$. This incorporation is beneficial for the environment and consequently the entire productive chain ${ }^{12}$.

Nevertheless, adding residual material in the clay modifies the drying process or drying linear shrinkage of the ceramic products. Therefore, this stage must be well controlled in order to avoid fissures and cracks in the final product $^{13-17}$.

Since there is no information of the utilization of sheep wool ash in civil engineering, the aim of this paper was to evaluate, the addition of $0,5,10,20$ and $30 \%$ of this residue in ceramic products through drying linear shrinkage process.

\section{Materials and Methods}

Approximately $300 \mathrm{Kg}$ of clay was collected from a brickyard and $120 \mathrm{~kg}$ of sheep wool residue was obtained from a textile factory. Both places are located in the city of Bagé, state of Rio Grande do Sul, Brazil.

The experimental procedure was accomplished following three stages. Initially, clay and sheep wool residue were previously treated. Secondly, the formulation was prepared and the product shaped by vacuum extrusion and pressing. Finally, the ceramic products were dried.

In the pre-treatment stage, the clay was reduced as observed in Figure $1(\mathrm{~A})$ and dried at $15^{\circ} \mathrm{C}$ for three weeks. Afterwards, the clay was grinded in a hammer mill, with hardness of 4-5 MOHS and power of $5.5 \mathrm{KW}$, followed by homogenization. 


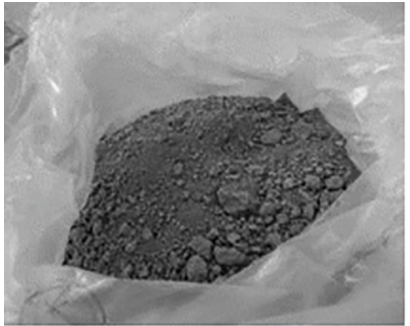

(A)

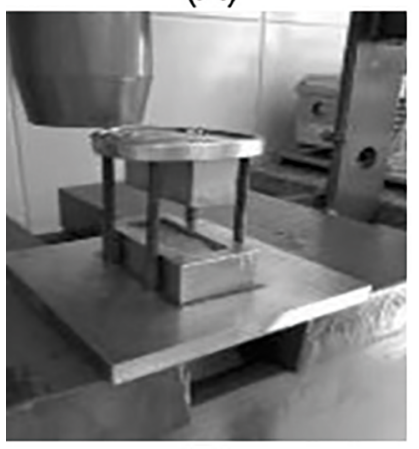

(D)

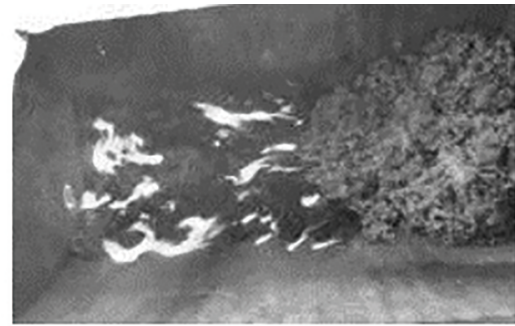

(B)

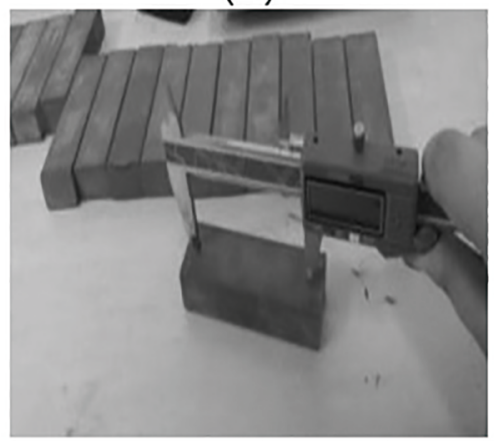

(E)

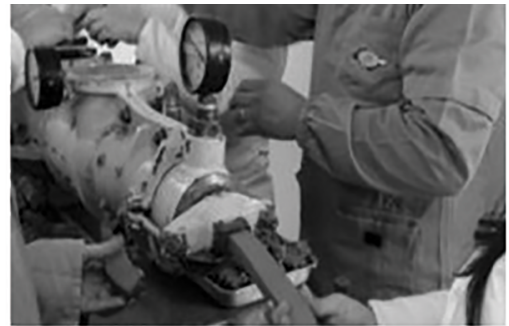

(C)

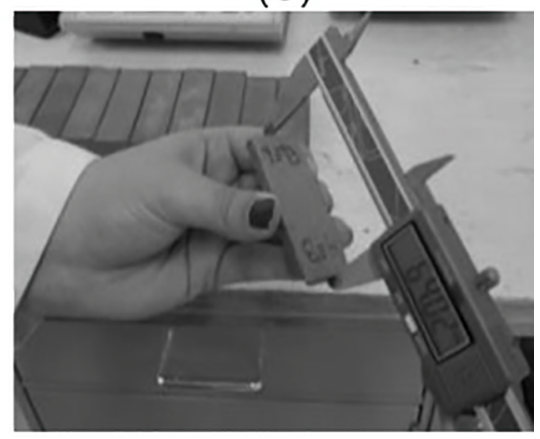

(F)

Figure 1. Clay pre-treatment (A), residue burning (B), vacuum extruder (C), steel mold used in pressing (D), metering of extruded (E) and pressed samples $(\mathrm{F})$.

In addition, the clay that was shaped by pressing was sieved through a 100-mesh sieve (Solotest,Brazil).

The sheep wool ash (CL) was prepared by burning the residue, which revealed some impurities including dirt, sand, insects, vegetal matter and manure. The burning process (Figure 1(B)) was performed at room temperature at the Federal University of Pampa (Unipampa). Several firings were carried out in order to break the fibers. Afterwards, the ash was sieved in a sequence of sieves up to 80 mesh $(0.177 \mathrm{~mm})$ sieve (Solotest) using a metallic agitator with a velocity of $9 \mathrm{rpm}$ for $8 \mathrm{~min}$. Only the fractions retained in the bottom of the 80-mesh sieve were selected to be added to the formulations.

The clay and sheep wool ash were submitted to the chemical test of Energy Dispersive X-ray Fluorescence (XRF/EDX). For analysis, the samples were sent to the Laboratory of Ceramic Materials (LACER) located at the Federal University of Rio Grande do Sul (UFRGS). Percentages (in mass) of clay and sheep wool ash used in the formulations are presented in Table 1.

In order to shape the products by vacuum extrusion, humidity was determined according to plasticity limits 18. The mixtures were watered until humidity reached a percentage of 28 to $35 \%$ for the extruded and 8 to $13 \%$ for the pressed samples. After moistened, the formulations were kept inside the plastic bags for $24 \mathrm{~h}$ in order to achieve regular water distribution.

The molding was done using the vacuum extruder (Vérdes, Brazil) with a volumetric capacity of $20 \mathrm{~m}^{3} / \mathrm{h}$ in the Civil Engineering Laboratory at the rural campus of the University
Table 1. Percentages of each formulation.

\begin{tabular}{lcc}
\hline Formulation & Clay(\%) & CL (\%) \\
\hline A0 & 100 & 0 \\
CL5 & 95 & 5 \\
CL10 & 90 & 10 \\
CL20 & 80 & 20 \\
CL30 & 70 & 30 \\
\hline
\end{tabular}

of Campanha region Twenty-five samples sized $10 \times 3 \times 3 \mathrm{~cm}$ with a prism format and rectangular base were used. Moreover, for the pressing method, a motorized hydraulic press (NOWAK, Brazil) was used. The compaction pressure was set at 5 ton. although the press had a capacity of 60 ton. In this method, the steel mold method was used, which is presented in Figure 1(D), in order to obtain the 25 pressed samples of each formulation with dimensions of $6.5 \times 2.5 \times 0.5 \mathrm{~cm}$.

In the dying stage, the extruded products were dried at approximately $15^{\circ} \mathrm{C}$ for 3 weeks. Afterwards, the samples were dried in an oven (SOLAB, Brazil, model SL10/150) for $48 \mathrm{~h}$ with gradual temperature increase from $40 \pm 5^{\circ} \mathrm{C}$ to $110 \pm 5^{\circ} \mathrm{C}$. For the pressed specimens, drying occurred firstly at $15^{\circ} \mathrm{C}$ for $24 \mathrm{~h}$, and then in an oven for $24 \mathrm{~h}$ at $110 \pm 5^{\circ} \mathrm{C}$.

The drying parameters of the specimens were monitored and determined according to the standard $\mathrm{C} 21 / 95$, which refers to characterization through length metering of the samples before and after drying. The stages clay pre-treatment, residue burning, molding of products by extrusion and by pressing, as well as drying of extruded and pressed samples are shown in Figure 1 (A), (B), (C), (D), (E) and (F), respectively. 


\section{Results and Discution}

The results obtained in the Energy Dispersive X-ray Fluorescence test for both clay and sheep wool ash are presented in Table 2.

Table 2. Results obtained in the chemical analysis of the clay and ash.

\begin{tabular}{lcc}
\hline Compounds & $\begin{array}{c}\text { Clay } \\
\text { (\% in mass })\end{array}$ & $\begin{array}{c}\text { Sheep wool ash } \\
\text { (\% in mass })\end{array}$ \\
\hline $\mathrm{SiO}_{2}$ & 57.54 & 1.88 \\
$\mathrm{Al}_{2} \mathrm{O}_{3}$ & 12.15 & 0.31 \\
$\mathrm{Fe}_{2} \mathrm{O}_{3}$ & 11.77 & 0.13 \\
$\mathrm{~K}_{2} \mathrm{O}$ & 2.67 & 0.73 \\
$\mathrm{MgO}$ & 1.12 & 0.09 \\
$\mathrm{CaO}$ & 1.11 & 0.35 \\
$\mathrm{TiO}_{2}$ & 0.81 & - \\
$\mathrm{Na}_{2} \mathrm{O}$ & 0.24 & - \\
$\mathrm{P}_{2} \mathrm{O}_{5}$ & 0.09 & 0.06 \\
$\mathrm{ZrO}_{2}$ & 0.07 & - \\
$\mathrm{SO}_{3}$ & 0.07 & 3.24 \\
$\mathrm{MnO}_{\mathrm{SrO}}$ & 0.04 & - \\
$\mathrm{Rb}_{2} \mathrm{O}$ & 0.03 & - \\
$\mathrm{ZnO}$ & 0.03 & - \\
$\mathrm{Y}_{2} \mathrm{O}_{3}$ & 0.03 & 0.02 \\
$\mathrm{C}$ & - & - \\
\hline
\end{tabular}

The compounds with the largest quantity of clay are $\mathrm{SiO}_{2}, \mathrm{Al}_{2} \mathrm{O}_{3}$ and $\mathrm{Fe}_{2} \mathrm{O}_{3}$, which resulted in $81.46 \%$ of clay composition as demonstrated in Table 2 . This composition is in accordance with the characteristic percentage of Kaolinite mineral clay ${ }^{19}$.

The compounds $\mathrm{K}_{2} \mathrm{O}$ and $\mathrm{Na}_{2} \mathrm{O}$ (alkaline oxides) have a total percentage of $2.91 \%$ in clay composition. ${ }^{19-20}$ reported that an elevated quantity of these compounds may cause internal stress and product crack. Moreover, the sheep wool ash is formed by carbon (C) with a percentage of $93.2 \%$. It is also important to highlight that the quantity $\mathrm{SO}_{3}$ found in the ash reaches a value of $3.24 \%$, which may cause efflorescence in the final product.

The average drying linear shrinkage and its standard deviation for each formulation and method used for the sample molding can be seen in Table 3 .
The average values of drying linear shrinkage varied from $6.70 \pm 0.25 \%$ to $8.68 \pm 0.23 \%$ for the extruded specimens and from $0.23 \pm 0.37 \%$ to $1.27 \pm 0.47 \%$ for the pressed ones. These results and their standard deviation are analogue to the values informed in the literature ${ }^{6,21}$.

Notably, it is possible to observe that the extruded sample CL30 (6.70 $\pm 0.25 \%)$ presented the lowest shrinkage average when compared with the different formulations as observed in Table 2. This is a result of the high percentage of sheep wool ash in its formulation. Therefore, it is possible to confirm that the high residue ash concentration in the extruded specimen decreases the linear shrinkage for the formulation (CL30) when compared to the other formulations, including (A0).

In contrast, for the samples molded by pressing, the lowest shrinkage average was obtained for the formulation A0 $(0.23 \pm 0.37 \%)$, which means that the extruded product presents an inverse behavior for drying linear shrinkage when compared to the pressed products.

According to the literature, when the drying linear shrinkage value is superior to $6 \%$ for extruded products, it means that the specimens may present volumetric variation during the drying period ${ }^{21}$. Some authors who analyzed the drying linear shrinkage of ceramic products with residue addition (in this case, rice husk ash) found values of $6.5 \%$ and $0.7 \%$ for extrusion and pressing methods, respectively. Therefore, the values obtained in this study are consistent to the expected for the extruded and pressed ceramic products ${ }^{22-23}$.

\section{Conclusion}

The physical plasticity index obtained for the formulations revealed that all results are in agreement with the values in the literature. The mass formulations were classified with high plasticity, in which the mass for extrusion was moistened from $28 \%$ to $35 \%$, and $10 \%$ for the pressing mass.

$\mathrm{X}$-ray fluorescence analysis showed significant presence of $\mathrm{SiO}_{2}, \mathrm{Al}_{2} \mathrm{O}_{3}$ and $\mathrm{Fe}_{2} \mathrm{O}_{3}$, which confirms Kaolinite characteristics of clay. For the ash, results indicated that $\mathrm{C}$ is the largest element of its composition.

Through the drying linear shrinkage test, it was possible to observe that the increase in ash percentage generated an analogue result for formulations A0, CL5, CL10 and CL20. However a decrease in linear shrinkage values was observed in the extruded CL30 samples. This means that, the utilization of higher percentages of ash in the formulations is possible for extrusion modeling. Whereas, it was observed that as

Table 3. Results of drying linear shrinkage for the extruded and pressed products.

\begin{tabular}{lccccc}
\hline \multirow{2}{*}{ Products } & \multicolumn{5}{c}{ Formulations } \\
& A0 & CL5 & CL10 & CL20 & CL30 \\
\hline Extruded & $8.59 \pm 0.19$ & $8.54 \pm 0.28$ & $8.49 \pm 0.28$ & $8.68 \pm 0.23$ & $6.70 \pm 0.25$ \\
Pressed & $0.23 \pm 0.37$ & $0.55 \pm 0.43$ & $0.64 \pm 0.26$ & $0.90 \pm 0.78$ & $1.27 \pm 0.47$ \\
\hline
\end{tabular}


the ash percentage increases, the linear shrinkage values also increase for the pressed samples, different from the extrusion method.

\section{Acknowledgements}

The authors would like to thank CAPES for financial support and URCAMP for making the Materials Laboratory available for use.

\section{References}

1. Freitas CSR, Pereira IAFS, Pereira MLG, Simões TCR, Ferreira AAL. Influência de Diferentes Processos de Conformação nas Características Finais de Produtos Cerâmicos. Cerâmica Industrial. 2009;14(3):15-18.

2. Moraes SS. Conceitos de metodologia de design aplicados ao projeto de produtos cerâmicos extrudados. [Dissertation]. Florianópolis: Department of Materials Science and Engineering - Federal University of Santa Catarina; 2010.

3. Iserhard JLRF. Estimativa do tempo de secagem de meios porosos inertes à base de argila em um modelo experimental. [Thesis]. Porto Alegre: Department of Mining, Metallurgy and Materials Engineering - Federal University of Rio Grande do Sul; 2009.

4. Weizenmann M, Bruxel FR, Santana ERR, Oliveira EC. Evaluation of gems sludge incorporation in red ceramic - a case study. Cerâmica. 2013;59(351):442-447.

5. Arsenović M, Radojević Z, Jakšić Ž, Pezo L. Mathematical approach to application of industrial wastes in clay brick production - Part I: Testing and analysis. Ceramics International. 2015;41(3 Pt B):4890-4898.

6. Floss MF, Thomé A. Adição de resíduo proveniente do corte e polimento de rochas basálticas em materiais de cerâmica vermelha. RECIE. 2006;15(1/2):1-7.

7. Haiying Z, Youcai Z, Jingyu Q. Utilization of municipal solid waste incineration (MSWI) fly ash in ceramic brick: Product characterization and environmental toxicity. Waste Management. 2011;31(2):331-341

8. Calvete R, Villwock LH. Perfil da ovinocultura de lã e carne do Rio Grande do Sul e seus desafios para o futuro. In: $X L V$ Congresso da Sociedade Brasileira de Economia, Administração e Sociologia Rural; 2007 Jul 22-25; Londrina, PR, Brazil; 2007. $21 \mathrm{p}$.

9. Santos DV, Azambuja RM, Vidor AC. Dados populacionais do rebanho ovino gaúcho. A Hora Veterinária. 2011;31(185):41-44.

10. Direction IED. Fibre preparation: natural fibres. Available from: $<$ ied.ineris.fr/sites/default/interactive/bref text/breftext/anglais/ bref/BREF_tex_gb5.html >. Access in 4/12/2016.
11. Devant M, Cusidó JA, Soriano C. Custom formulation of red ceramics with clay, sewage sludge and forest waste. Applied Clay Science. 2011;53(4):669-675.

12. Collato D. Utilização de resíduo proveniente da estação de tratamento de efluentes de indústria de papel como matériaprima na fabricação de cerâmica vermelha [Dissertation]. Porto Alegre: Department of Mining, Metallurgy and Materials Engineering - Federal University of Rio Grande do Sul; 2008.

13. Dias LG. Estudo do processo de secagem em estufa e por microondas de compósitos cerâmicos de argila e resíduos de esteatito. [Dissertation]. São João Del Rei: Department of Energy Engineering - Federal University of São João Del Rei; 2013.

14. Tubino LCB, Borba PE. Dossiê Técnico. Etapas do Processo Cerâmico e sua Influência no Produto Final - massa, extrusão, secagem e queima. SENAI-RS - Centro de Educação Profissional SENAI Nilo Bettanin. Esteio - Rio Grande do Sul; 2006. Available from: $<\mathrm{http}: / /$ www.respostatecnica.org.br/dossietecnico/ downloadsDT/NDI $>$. Access in: 8/5/2016.

15. Basin. Technical Brief - Drying of clay bricks and tiles. Technical Brief - Building Advisory Service and Information Network. Germany Gate; 2000. Available from: <https://pt.scribd.com/ document/321317000/Drying-of-Clay-Bricks-and-Tiles-2000Merschmeyer-pdf $>$. Access in: 9/5/2017.

16. Vieira CMF, Feitosa HS, Monteiro SN. Avaliação da secagem de cerâmica vermelha através da Curva de Bigot. Cerâmica Industrial. 2003;8(1):42-46.

17. Lopes DC. Estudo da viabilidade de adição de resíduo de pó de fumo à massa cerâmica. [Dissertation]. Santa Maria: Department of Civil Engineering - Federal University of Santa Maria; 2005. $94 \mathrm{p}$.

18. Associação Brasileira de Normas Técnicas. NBR 7180. Solo - Determinação do Limite de Plasticidade. Rio de Janeiro: Associação Brasileira de Normas Técnicas; 1984. 3 p.

19. Kniess CT. Desenvolvimento e caracterização de materiais cerâmicos com adição de cinzas pesadas de carvão mineral. [Thesis]. Florianópolis: Federal University of Santa Catarina; 2005.

20. Fernandes PF. Reaproveitamento do lodo da estação de tratamento de efluentes de uma indústria cerâmica. [Dissertation]. Florianópolis: Federal University of Santa Catarina; 2002.

21. Oliveira GE, Holanda JNF. Reaproveitamento de resíduo sólido proveniente do setor siderúrgico em cerâmica vermelha. Cerâmica. 2004;50(314):75-80.

22. Quintana LMH, Soares JMD, Frizzo PP, Bohrer LD. Utilização da cinza de casca de arroz na produção de cerâmica vermelha.

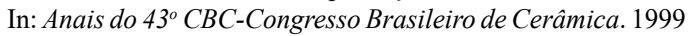
Jun 2-5; Florianópolis, SC, Brazil. p. 15001-15010.

23. Medeiros FK, Aquino RCA, Rodrigues AMT, Silva HC, Dias IBC, Ferreira HS. Produção de tijolos maciços e placas cerâmicas de revestimento com adição de óleo lubrificante usado. Cerâmica Industrial. 2014;19(2):38-45. 